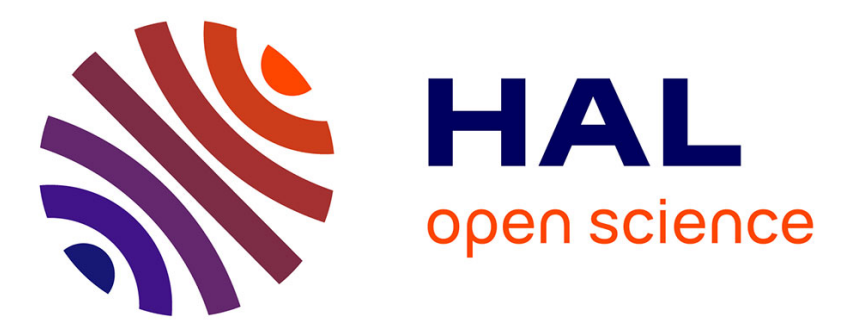

\title{
Cooperative Learning in Physical Education and Acceptance of Students with Learning Disabilities
}

Amaël André, Pascale Deneuve, Benoit Louvet

\section{To cite this version:}

Amaël André, Pascale Deneuve, Benoit Louvet. Cooperative Learning in Physical Education and Acceptance of Students with Learning Disabilities. Journal of Applied Sport Psychology, 2011, 23 (4), pp.474-485. 10.1080/10413200.2011.580826 . hal-02139667

\section{HAL Id: hal-02139667}

\section{https://hal-normandie-univ.archives-ouvertes.fr/hal-02139667}

Submitted on 5 Jun 2019

HAL is a multi-disciplinary open access archive for the deposit and dissemination of scientific research documents, whether they are published or not. The documents may come from teaching and research institutions in France or abroad, or from public or private research centers.
L'archive ouverte pluridisciplinaire HAL, est destinée au dépôt et à la diffusion de documents scientifiques de niveau recherche, publiés ou non, émanant des établissements d'enseignement et de recherche français ou étrangers, des laboratoires publics ou privés. 


\title{
Cooperative Learning in Physical Education
}

\section{and Acceptance of Students with Learning Disabilities}

\section{Amael ANDRE, Pascale DENEUVE et Benoit LOUVET}

\begin{abstract}
The present study examined the effect of cooperative learning on the acceptance of mainstream students with learning disabilities in physical education regular classes and the links between these students' acceptance and their athletic abilities. Eight mainstream sixth grade classes were assigned either in a cooperative group $(n=112)$ or in an individual group $(n=105)$. The cooperative classes practiced in a cooperative learning structure. The sociometric rating techniques were used to assess the acceptance. The results showed that the instructional structure influenced the acceptance of mainstream students, and that these students' athletic abilities were related to their acceptance.
\end{abstract}

\section{Key words:}

cooperative learning, disability, athletic abilities, physical education, peer acceptance

\section{Introduction}

In French middle schools, students with learning disabilities are gathered in special classes called S.E.G.P.A. (i.e., Section d'Enseignement Générale et Professionnelle Adaptée) for general and vocational education. According to Sabornie, Evans, and Cullinan's (2006) classification, S.E.G.P.A. students are considered as students with learning disabilities because of their very poor writing and reading performances. However, they are not mentally retarded and they do not have any major behavioral problems. Given that they are in segregated special classes in the same school as regular students, S.E.G.P.A. students are often stigmatized and rejected by their schoolmates (Pasquier, 1999). 
The integration of S.E.G.P.A. students in regular classes is promoted by the guidelines of the French Education Department (2002) in order to develop social integration (i.e., positive social relationships between students). Peer acceptance is a sign of social integration (Haring, 1991). The concept of peer acceptance has been defined as the degree to which individual pupils are accepted or rejected by members of their peer group (Bukowski \& Hoza, 1989). One of the indicators of the level of peer acceptance is the sociometric status (Maassen \& Vershueren, 2005). According to Hymel, Vaillancourt, Mac Dougall, and Renshaw (2002), sociometric indexes offer a unique window into how individuals are accepted within the social structure and the degree to which they can really fit in with a group. The sociometric status is characterised by two dimensions (Frederickson \& Furnham, 1998). On the one hand, social preference means being liked or rejected by one's peers. On the other hand, social impact corresponds to the fact of being noticed by one's peers. In the field of special education, the sociometric status of mainstream children with learning disabilities in different national school systems has consistently been found to be low (Ochoa \& Olivarez, 1995; Shessel \& Reiff, 1999).

In French middle schools, integration in Physical Education (PE) classes is recommended by the Education Department (2002) in order to facilitate the acceptance of S.E.G.P.A. students. PE enables these students to reach the abilities of regular students because this discipline does not primarily require intellectual abilities. However, the results of the studies carried out by Garel (2001) showed that integrating students in PE did not always lead to a better acceptance of S.E.G.P.A. students. Sometimes, it caused these pupils to be more rejected by their peers. Therefore the elements that impact on the social integration of S.E.G.P.A. students in PE still need to be identified.

In PE and sport literature, very few studies deal with the integration of students with learning disabilities. Mitigated results are reported. Deneuve, Genty, and Dru (2002) showed the impact of the type of sport on the sociometric status of students with learning disabilities in PE 
over eight lessons in primary school. The results indicated that acrobatic actions in gymnastics positively affected the acceptance of these students as opposed to throwing activities. Yet this research only studied the acceptance of these students in an individual condition (i.e., each student practiced an acrobatic action individually). Nonetheless, a recent study conducted by André, Deneuve, and Louvet (2010) indicated that in middle schools, an individual condition in acrobatic activities was not sufficient to lead to a better acceptance of S.E.G.P.A. students in PE. The results showed that at the end of seven weeks of experimentation, the sociometric indexes of S.E.G.P.A. students remained stable. Consequently, it would seem accurate to study the impact of acrobatic actions in gymnastics on the acceptance of students with learning disabilities in cooperative conditions.

Indeed, many studies have pointed out the impact of Cooperative Learning (CL) on peer relationships in academic contexts (Gillies \& Ashman, 1998; Jordan \& Lemetals, 1997). CL is an instructional format in which students work together in small, structured, heterogeneous groups to master the content of a lesson (Putnam, 1998). CL may be contrasted with individualistic learning in which students work independently to achieve learning goals unrelated to those of other students (Johnson \& Johnson, 1989). In the field of special education, CL positively affects the social relationships between regular students and students with physical or intellectual disabilities (Lloyd, Crowley, Kohler, \& Strain, 1988; Margolis \& Freund, 1991). It has also been demonstrated that it promotes positive interactions between students with learning disabilities and regular students (Gillies \& Ashman, 2000; Putnam, Rynders, Johnson, \& Johnson, 1989). Using sociometric methods, some researchers indicated that CL generates significant increases in the peer acceptance of students with learning disabilities by regular students as opposed to individualistic learning in elementary schools (Jacques, Wilton, \& Townsend, 1998; Piercy, Wilton, \& Townsend, 2002). Putnam, Markovchick, Johnson, and Johnson (1996) indicated that positive changes in sociometric peer ratings of special-education students in the 11-15 age 
bracket by their regular classmates occurred more frequently in the CL conditions than in the individualistic learning conditions.

According to Johnson \& Johnson (1989), five main elements distinguish CL from individualistic learning: promoting face-to-face interaction, positive interdependence, individual accountability, interpersonal and small-group skills, and group processing. First, promoting faceto-face interaction is effective when small groups are created, and the group members are working on a task in close proximity to one another. Second, positive interdependence is achieved when group members learn how to depend on the rest of the group while working together to complete the task. Third, individual accountability requires individual contributions to group goals. Individual students demonstrate what they have learnt as a result of participating in cooperative activities. Fourth, interpersonal and small-group skills such as shared decisionmaking, taking responsibilities and initiatives, or giving and receiving feedback are developed through tasks involving collective work. Finally, group processing is a debriefing session after the learning task. It is the time devoted to discussions on how group members are achieving their goals and maintaining effective working relationships. According to Johnson and Johnson (2000), these elements must be taken in account to achieve positive relationships between regular and stigmatized students.

In PE and sport-related literature, several writers have encouraged the use of CL as an instructional model because of its focus on social goals in addition to motor skills (Barrett, 2005; Dyson, Griffin, \& Hastie, 2004). However, according to Barett (2005) "there is only a beginning literature on CL in PE" (Barrett, 2005, p. 89). CL structures in PE can promote motor skills and social interactions of pre-school and elementary school children (Grineski, 1993). Barrett (2005) studied the way sixth grade physical education classes used CL methods. The CL structure was based on complementary roles of coach and performer, peer assesment, and team rewards. The author found CL managed to increase students' percentage of correct trials compared to 
individualistic learning methods. Polvi and Telama (2000) investigated fifth grade students' development of social helping behavior in PE by using CL. The authors found that students in the experimental group who were systematically assigned new partners helped their teammates more than students who belonged to stable groups with partners they had chosen or students who had worked individually. Goudas and Magotsiou (2009) reported that the implementation of a CL program in basket-ball, volleyball, and traditional Greek dancing sessions enhanced social skills and attitudes toward group work of students from sixth grade. Using qualitative methods, Dyson (2002) showed CL learning encouraged greater peer support and positive student-to-student interactions in volleyball and basketball units with students from third and fourth grade. In this study, students were responsible for taking different roles such as coach, organizer, recorder, and encourager. The results indicated the importance of taking various roles in small groups. Mascret (2009) stressed the importance of creating a positive interdependence between students in an individual sport thanks to a common result. Adding the coach's and the player's results enabled to increase social skills for sixth-grade French failing students in a CL structure in badminton. However, as far as we know, there is no study that deals with the impact of CL in PE on the peer acceptance of students with learning disabilities.

Another factor linked with peer acceptance has been identified in sport literature: athletic skills. In a review, Weiss and Stuntz (2004) reported that peer acceptance was linked with athletic skills (actual or perceived). Studies have consistently revealed that peer acceptance and physical ability are tightly linked. For example, Boivin and Begin (1989) found that the most popular third- and fourth-grade children showed higher levels of self-perceived athletic skills and received higher athletic performance ratings from their teachers than children who were rejected. Using sociometric measures, Landers-Pott and Grant (1997) observed the role of actual athletic skill on the peer status of boys and girls -between 5 and 8- playing soccer or basketball. Perceived athletic skill was a major indicator of peer status among youngsters. Caussgrove, 
Dunn, and Bayduzza (2007) also showed that higher levels of peer acceptance corresponded to higher levels of other-rated athletic skill for fourth to sixth graders aged between eight and ten. Weiss and Duncan (1992) found a strong positive correlation between peer acceptance and perceived athletic skills in a sample of 8-13 year-old kids in a sport context. Yet these studies do not deal with the acceptance of mainstream students with learning disabilities.

Deneuve et al. (2002) indicated that athletic skills in gymnastics of mainstream students with learning disabilities were strongly linked with peer acceptance in elementary school (students aged between nine and ten). Sociometric scores obtained by these students were correlated with their actual athletic skill scores in gymnastics. It seems appropriate to find out whether these results also apply to 11-12 year-old preadolescents with learning disabilities.

This study had a dual aim. On the one hand, the impact of the instructional structure (i.e,. cooperative versus individual) on the acceptance of S.E.G.P.A. students was studied. On the other hand, the links between the acceptance of S.E.G.P.A. students and their athletic skills in gymnastics were analyzed.

\section{Method}

A quasi-experimental design was adopted in a real-educational setting.

\section{Participants}

Students from twelve sixth-grade classes from four schools took part in the experiment $(n$ $=217, M_{\text {age }}=11.8$ years $)$. One hundred and eighty-five students ( 98 boys and 87 girls) belonged to eight regular classes and the 32 others ( 24 boys and 8 girls) were part of four S.E.G.P.A. classes. The regular classes consisted of children from working-class backgrounds with an average academic level. With the help of the administrators in charge of the special classes, S.E.G.P.A. students who did not behave aggressively were selected. Their recruitment was especially based on their extremely poor performance in intellectual tasks, notably in reading and 
writing. The S.E.G.P.A. pupils came from poor and working-class families and were punctually integrated into regular classes s in music, technology, and PE. The selected S.E.G.P.A. and ordinary pupils did not have any specific experience in gymnastics. The teachers involved informed parents of the study, and all the participants gave their consent before participating.

The four teachers who took part in the experiment were volunteers. They had over seven years of teaching experience and they all attended a 2-day course organized by the French Ministry of Education. The course focused on the implementation of cooperative learning methods in PE.

\section{Organization device}

Four S.E.G.P.A. students (three boys and one girl) were integrated into each of the eight regular classes. This kind of mainstreaming is usually used in French middle schools (Garel, 2001). First, welcoming activities were organized in order to make sure the students got to know each other. In the eight mainstream classes, regular students and S.E.G.P.A. students took a sociometric test (pretest). Second, the eight classes practiced six two-hour lessons of gymnastics over a 5-week period. These classes were chosen at random for one of the two treatment conditions. One hundred and five students (89 regular students and 16 S.E.G.P.A. students) from four mainstream classes (class A: 28 students, class B: 25 students, class C: 27 students, class D: 25 students) practiced in an individual learning structure (individual classes), and 112 students (96 regular students and 16 S.E.G.P.A. students) from the four other mainstream classes (class E: 28 students, class F: 28 students, class G: 28 students, class H: 28 students) practiced in a CL structure (cooperative classes). During the last lesson, the skills in gymnastics were rated by two experts in gymnastics. Finally, two weeks after the last lesson, all the students took the sociometric test (posttest).

The four teachers taught both the cooperative and the individual classes without any incitement from the researchers in order to favor CL over individualistic learning. 


\section{Procedure}

Cooperative classes. Learning team structure was implemented in gymnastics. According to Dyson and Grineski (2001), it can readily be applied to almost every PE content. The five elements stressed by Johnson and Johnson (1989) are implemented in this structure: (a) In each class, the students were divided into seven teams of four. Four teams included one S.E.G.P.A. student. The positioning of teams in different sections of the gymnasium encouraged face to face interactions. After each lesson, the S.E.G.P.A. students changed teams (Polvi et Telama, 2000). Thus all the regular students worked with a SEGPA student during three 2-hour lessons; (b) Positive interdependence was structured. Indeed the results were shared by all the group members because the team results were based on the addition of each team member's score (Mascret, 2009); (c) Each team member was individually accountable because they each had a role to play. Complementary roles were assigned within each team. A team was composed of one gymnast, two helpers, and one judge. After three attempts, the students were asked to exchange roles; (d) The motor and social skills required to achieve the goal were described by the teacher and listed on a task-sheet. These social skills were required in the tasks as the helpers had to hold the gymnasts during the activity to help them succeed and to prevent them from falling. The judge had to give feedbacks and to write the level reached according to the execution criteria mentioned on the task-sheet. Then each student's performance could be assessed by group members; (e) During a debriefing period of five minutes at the end of the class, the students assessed -with the teacher- how well their group had functioned through group processing.

Individual classes. As opposed to CL structure, individualistic learning was implemented in individual classes: (a) The students worked individually because no group was created; (b) the results were individual; (c) the roles were not assigned; (d) Only the motor skills required in the tasks were described by the teacher and listed on a task sheet. The students' skills were assessed 
by the teacher; (e) During a debriefing period of five minutes, the students evaluated their own results and problems with the teacher.

Treatment fidelity. In order to check fidelity, the second and the fifth lessons were observed in each class thanks to a checklist. For the cooperative condition, the criteria were the following: (a) team formation, (b) team rewards, (c) role assignment, (d) explanation on motor and social skills and peer assessment, and (e) group processing. For the individual condition, the criteria were the following: (a) individual working, (b) individual results, (c) presence of a single role (i.e., gymnast), (d) explanation on motor skills and assessment by the teacher, and (e) debriefing periods on the individual results. In each class, all the requirements were met. The treatment conditions were fully respected.

\section{Instruments}

Sociometric ratings. The Sociometric Rating Scale techniques (Oden \& Asher, 1977) were used to assess peer acceptance of S.E.G.P.A. students. The sociometric rating method is suitable to measure acceptance (Maassen, Van der Linden, Goossens, \& Bokhorst, 2000). The use of the rating method has several advantages. It collects a great deal of information enabling broader pictures of social groups and overall acceptance levels to emerge. Moreover it is more acceptable at school than negative nomination practices. Finally, Maassen and Verschueren (2005) indicated that the rating methods improved the validity and the reliability of sociometric indexes. Such a method consists in asking the pupils to evaluate every other group from one or two questions dealing with degree of liking or desirability as a social partner. The available data (Cillessen and Bukowski, 2000) suggest that acceptance items that look into liking by your peers have psychometric properties that are similar to items that look into desirability as a social partner and assess aspects of acceptance that are closely linked. A signle item was used in the present study because of the high concentration disruption encountered by SEGPA students in an intellectual task. Some studies showed that single items can be both reliable and valid measures of an 
affective or cognitive construct (Abdel-Khalek, 2006; Jordan \& Turner, 2008). According to Frederickson and Furhman, (1998) the sociometric criteria used in assessing the sociometric status of mainstream children with learning disabilities should refer to specific situations and activities in which mainstream children with learning difficulties have opportunities to associate with their peers.

The method resorted to by Frederickson and Furnham (1998) was used to assess peer acceptance indexes of mainstream students with learning disabilities. In each mainstream class, all the students were presented with a complete list of each other's names and asked the following question: 'How much would you like to play sport with X ...?” The students were given four alternatives. The first was a smiley indicating they would have liked to play sport with this student. The second was a neutral face indicating they did not mind playing sport with this student. The third was a sad face indicating they would not have liked to play with her or him. The last alternative was a question mark enabling the students to indicate they did not know this student enough to give an answer. The students had to circle one of the four symbols for every other student. The social preference score of each student was calculated as follows: the number of smiley faces received minus the number of sad faces received. A preference index was calculated by dividing the social preference score received by the total number of students who answered. The social impact score was calculated as follows: the number of smileys received plus the number of sad faces. A social impact index was then calculated by dividing this score by the total amount of students who answered. The two indexes ranged from -1 to 1 .

Individual classes were used to assess reliability. The tests took place seven weeks apart. The correlation between the pretest and the posttest was 0.68 for the preference indexes and 0.71 for the impact indexes. Thus sociometric indexes were stable.

Competence ratings. Students were rated by two gymnastics experts at the last lesson. Eight acrobatic activities referenced in French PE guidelines (i.e., forward rotation, backward 
rotation, getting over an obstacle, making a handstand, a cartwheel, swaying, jumping on a beam, and making a loop on a horizontal bar) were performed by each student. Each action was assessed on six points according to a rating code commonly used with sixth graders as well as with pupils with learning disabilities (Duboz, Policarpo, \& Héraud, 2000). Three points were devoted to task difficulty (e.g., rotations and aerial actions), and three points were devoted to execution criteria (e.g., amplitude, balance, and posture). The inter observer agreement was very $\operatorname{good}(\mathrm{ICC}=.92)$.

\section{Data Analysis}

Four ANOVAs, Class (cooperative versus individual) $\times$ Time (pretest versus posttest), with repeated measures were conducted on each of the dependent variables (i.e., preference indexes of S.E.G.P.A. students, preference indexes of regular students, impact indexes of S.E.G.P.A. students, and impact indexes of regular students) to examine the influence of the instructional format on the acceptance of students.

Correlations between the scores of athletic skills and sociometric indexes at the last lesson were measured by using Bravais-Pearson's correlation coefficient in order to identify the links between athletic skills and the acceptance of S.E.G.P.A. students by their peers.

\section{Results}

\section{Influence of Instructional Structure on Sociometric Indexes}

The means and standard deviations of sociometric indexes in cooperative classes and individual classes at the pretest and at the posttest are presented in Table 1. An independent t-test conducted on the preference indexes confirmed that S.E.G.P.A. students were significantly less accepted than their regular counterparts at the beginning of the experimentation, $t(215)=-6.73, p$ $<.001, r=0.42$. 
The ANOVAs (i.e., Class x Time) with repeated measures conducted on impact indexes showed no significant results neither for S.E.G.P.A. students nor for regular students. Indeed, for S.E.G.P.A. students, the interaction effect (i.e., Class x Time) was not significant $F(1,30)=1.37$, $p>.05$, and the main effects of time and of class were also insignificant, $F(1,30)=0.35, p>.05$, $F(1,30)=1.18, p>.05$, respectively. For regular students, the interaction effect (i.e., Class $\mathrm{x}$ Time) was not significant $F(1,183)=0.39, p>.05$ and the main effects of time and of class were also non-significant, $F(1,183)=0.01, p>.05, F(1,183)=2.08, p>.05$, respectively.

The ANOVAs (i.e., Class x Time) with repeated measures conducted on preference indexes revealed a different pattern of results even if, for regular students, the interaction effect (i.e., Class $\mathrm{x}$ Time) did not appear to be significant, $F(1,183)=0.87, p>.05$, just like the main effects of time, $F(1,183)=0.65, p>.05$, and of class, $F(1,183)=0.07, p>.05$. Of particular interest is the significant interaction effect Class $x$ Time found on preference indexes of S.E.G.P.A. students, $F(1,30)=5.78, p<.05, \eta_{\mathrm{p}} 2=.16$. The type of treatment applied during the time of the experimentation had a major influence over the preference indexes obtained by S.E.G.P.A. students. This interaction effect was calculated and is provided in Figure 1.

Subsequent analyses confirmed that S.E.G.P.A. students received identical preference indexes at the pretest regardless of the treatment class, $t(30)=-0.07, p>.05$. A different effect appeared in the posttest. Indeed, S.E.G.P.A. students enrolled in a CL class obtained higher preference indexes $(M=-0.09, S D=0.04)$ than their counterparts $(M=-0.25, S D=$ 0.04) who belonged to an individual learning class, $t(30)=2.75, p<.01, r=0.45$. The preference indexes increased significantly between the pretest $(M$ cooperative $=-0.23, S D=0.05)$ and the posttest $(M$ cooperative $=-0.09, S D=0.04)$ for the students in a CL setting, $t(15)=-2.25, p<.05, r=$ 0.50 , whereas they remained the same for the students in an individual learning setting, $t(15)=$ $0.90, p>.05$ 


\section{Correlation between Competence Scores and Sociometric Indexes of S.E.G.P.A. Students}

The measurement of the correlation using Bravais-Pearson's correlation coefficient showed a moderate significant correlation between skill scores and preference indexes of S.E.G.P.A. students, $r=0.62, p<.05$. No significant correlation was found between competence scores and impact indexes of S.E.G.P.A. students, $r=-0.11, p>.05$. The preference indexes of S.E.G.P.A. students were strongly correlated with skill scores for individual classes, $r=0.72, p<.001$, but the correlation was not significant for cooperative classes, $r=0.42, p>.05$. No significant correlation was found between impact indexes of S.E.G.P.A.students and skill scores for individual classes, $r=-0.14, p>.05$, and for cooperative classes, $r=0.16, p>.05$.

\section{Discussion}

This experiment had a double purpose. On the one hand, the impact of instructional structure on the acceptance of S.E.G.P.A. students by their peers was analyzed. On the other hand, the links between S.E.G.P.A. students' acceptance and athletic skills in gymnastics were studied.

Concerning our first objective, the results indicated that the type of structure (cooperative versus individual) set up in gymnastics affected the acceptance of S.E.G.P.A. students. Indeed, the preference indexes of these students increased more significantly for the cooperative classes than for the individual classes. These results are consistent with the studies carried out on the impact of CL structures compared to individual learning structures on the acceptance of students with learning disabilities in the field of intellectual tasks (Jacques et al., 1998; Piercy et al., 2002). In cooperative classes, the students played the complementary roles (Dyson, 2002) of helpers, gymnasts and judges, which facilitated the coordination of the students' efforts. Furthermore, they shared a common result (Mascret, 2009) since the scores were combined. Johnson and Johnson (2000) suggest that positive interdependence is an important condition in 
alleviating the rejection of students from minority groups in schools such as S.E.G.P.A. students in French middle schools. It can be argued that positive interdependence was all the more significant as the students were engaged in risk-taking situations. Indeed, the gymnasts sometimes had to perform high somersaults and rotations. Thus, risk-taking could give considerable value to the cooperation between regular and S.E.G.P.A. students. In this study, the helpers were responsible for the gymnasts' physical safety by preventing falls. Their presence surely facilitated the involvement of some students. It would be interesting to carry out further studies with a view to analysing the influence of risk-taking within CL structures on the acceptance of S.E.G.P.A. students. Finally, this interdependence could have favoured both verbal and physical interactions through advice given by judges and thanks to helpers' actions. Dyson and Grineski (2001) pertinently observed that CL in PE could give students opportunities to interact positively. This interaction requires cooperative ability from the S.E.G.P.A. students. This ability is a factor accounting for the acceptance of such students by their peers (Newcomb, Bukowski, and Pattee, 1993).

The results showed that the preference indexes of S.E.G.P.A. students significantly increased in cooperative classes whereas no significant modification appeared for students working in individual classes. These results are in keeping with the conclusions of André et al. (2010) in French middle schools. However, they are opposed to those obtained by Deneuve et al. (2002) concerning the impact of doing gymnastics under individual conditions on the change in the acceptance of students with learning disabilities in primary schools. It could be argued that middle school students were more resistant to change than those in primary school as the stigmatization of S.E.G.P.A. students is stronger in middle schools. As Pasquier (1999) showed, the identification of S.E.G.P.A. students appeared systematically linked to the structure they belonged to as well as to a specific geographical area within the school. Thus, the acceptance of S.E.G.P.A. students could lead to a risk of social devaluation for regular students, particularly for 
pre-teenage boys sensitive to the status of the group they belong to. It would be interesting in some further research to go beyond the level of interpersonal relationships and to examine the relationship between regular and S.E.G.P.A. students at intergroup level.

The results showed that the sociometric indexes of regular students remained unchanged whatever the structure put in place. It can be suggested that the relational structure within regular classes was stable. A twelve-hour experiment was not sufficient to change this structure. Moreover, it should be noted that the impact indexes of S.E.G.P.A. students remained stable under both conditions. The impact indexes of S.E.G.P.A. students right from the pretest were high and close to those of regular students. Right from the pretest, the S.E.G.P.A. students were identifiable and rejected simply because of the label that was attached to them. From that moment on, the increase in the acceptance of S.E.G.P.A. students was particularly dependent on the increase in the peer preference through the number of positive designations.

Concerning the second aim of the study, the results showed that the skill scores of the S.E.G.P.A. students in individual classes were significantly related to their preference indexes. They are in keeping with several studies carried out on the relationship between athletic skills and the acceptance of 11-12 year-old students (Causgrove et al., 2007; Duncan \& Weiss, 1992) and with those obtained by Deneuve et al. (2002) on mainstream students with learning disabilities in elementary schools. This phenomenon is probably increased by the fact that students demonstrated their skills during acrobatic activities at an age when risk-taking and risk control were factors that accounted for popularity (Assailly,1992). Nonetheless, the relations between the gymnastic skills of S.E.G.P.A. students and their acceptance must be balanced against the type of structure implemented. Indeed, the results of our study indicated that the preference indexes of S.E.G.P.A. students in a cooperative group provided no significant correlation with the skill scores. It can be suggested that cooperative interaction alleviated the impact of athletic skills. The acceptance of S.E.G.P.A. students was assuredly also linked to their 
skills in the roles of helpers and advisers. Newcomb et al. (1993) indicated that cooperative ability accounted for peer acceptance. Furthermore, it can be argued that individual comparisons of gymnastic skills were more important in individual classes. In these classes, the students were observed individually as their results were written and announced, making gymnastic skills highly conspicuous. On the other hand, the students' skills in the cooperative structure were assessed in groups of four and the results written and announced were both individual and collective. Our study showed, therefore, that the influence of individual athletic skills on the acceptance of students with learning disabilities by their peers was alleviated by the setting up of CL structures.

Although this research reveals some effects of CL in PE on the acceptance of S.E.G.P.A. students and the links between acceptance and athletic skills, the results need to be examined with care. First, S.E.G.P.A. students represent a specific population because they are poor performers in reading and writing and do not appear to fall within the traditional definition of adapted PE students. This limits the extent to which these results could be generalized to other groups regarded as disabled. The results of previous research carried out into academic subjects have revealed that cooperative learning can increase the acceptance of students with intellectual or physical disabilities (Lloyd et al., 1988; Margolis \& Freund, 1991). The impact of CL in PE on the acceptance of students with various disadvantages should be studied in further research programs. Second, it is not known whether continual use of the CL structure could facilitate even greater peer acceptance of S.E.G.P.A. students or whether the effects would last beyond a sevenweek experiment. It would be interesting to continue this study over a longer period covering several cycles to know if the results obtained continue. Third, this acceptance has only been measured by resorting to the sociometric method. It would be interesting in a future study to use complementary tools allowing the observation of behavioural interactions between regular and S.E.G.P.A. students within CL structures. 
To conclude, this study showed the significant impact of CL structures in gymnastics compared to an individual learning structure on the acceptance of S.E.G.P.A. students. Moreover, it showed that the acceptance of S.E.G.P.A. students was linked to gymnastic skills under individual conditions but not under cooperative conditions. Once again, the idea that simple mainstreaming automatically leads to a rise in acceptance is challenged. These results invite PE teachers to think about the structures to be set up when integrating S.E.G.P.A. students into regular classes. The assignment of complementary roles within cooperative teams composed of regular and S.E.G.P.A. students and the combining of individual results appear to be a promising first step towards the social integration of students with learning disabilities into PE classes. Integrating students with learning disabilities in PE is a complex phenomenon. Further studies in other sports, with other populations, and measurement of interactions are necessary to help physical educators to better understand the effects of mainstreaming students through PE. 


\section{References}

Abdel-Khalek, M. A. (2006). Measuring happiness with a single-item scale. Social Behavior and Personality, 34, 139-150.

André, A., Deneuve, P., \& Louvet, B. (2010). Danse hip-hop et discriminations entre les élèves de l'enseignement général et les élèves de S.E.G.P.A. [Hip-hop dancing and discriminations between regular students and S.E.G.P.A. students]. Carrefours de l'Education, 29, 25-40.

Assailly, J. P. (1992). Les jeunes et le risque [Youngs and risk]. Paris: Vigot.

Barrett, T. (2005). Effects of cooperative learning on the performance of sixth-grade physical education students. Journal of Teaching in Physical Education, 24, 88-102.

Boivin, M., \& Begin, G. (1989). Peer status and self-perception among early elementary school children: The case of the rejected children. Child Development, 60, 591-596.

Bukowski, W. M., \& Hoza, B. (1989). Popularity, friendship : Issues in theory, measurement, and outcome. In T. J. Berndt \& G. W. Ladd (Eds.), Peer friendships in child development (pp. 23-37). San Fancisco: Jossey-Bass.

Causgrove Dunn, J., Dunn, J. G., \& Bayduza, A. (2007). Perceived athletic competence, sociometric status and loneliness in elementary school children. Journal of Sport Behavior, $30,249-264$.

Cullinan, D. A., Sabornie, E. J., \& Crossland, C. L. (1992). Social mainstreaming of mildly handicapped students. Elementary School Journal, 92, 339-351.

Deneuve, P., Genty, J., \& Dru, V. (2002). Modification des affinités interpersonnelles intergroupes en fonction du type d'activité partagée et des compétences perçues en milieu scolaire [Change of interpersonal intergroup affinities according to the kind of activities and the perceived competences in an academic environment]. Les Cahiers Internationaux de Psychologie Sociale, 54, 71-76. 
Duboz, S., Policarpo, D., \& Héraud, A. (2000). Acro-gym: code de pointage [Acrobatic Gymnastic: rating code]. Paris: Editions revue EP.S.

Dyson, B., Griffin, L., \& Hastie, P. (2004). Sport education, tactical games, and cooperative learning: Theoretical and pedagogical considerations. Quest, 56, 226-240.

Dyson, B. (2002). The implementation of cooperative learning in an elementary physical education program. Journal of Teaching in Physical Education, 22, 69-85.

Dyson, B., \& Grineski, S. (2001). Using cooperative learning structures in Physical Education. The Journal of Physical Education, Recreation and Dance, 72, 28-31.

Frederickson, N. L., \& Furnham, A. F. (1998). Sociometric-status-group classification of mainstreamed children who have moderate learning disabilities: An investigation of personal and environmental factors. Journal of Educational Psychology, 90, 772-783.

Garel, J. P. (2001). L’intégration des élèves de S.E.G.P.A. en Éducation physique et sportive : entre espoirs et illusions [S.E.G.P.A.s integration in physical education: between hopes and illusions]. La Nouvelle Revue de l'AIS, 14, 61-71.

Gillies, R. M., \& Ashman, A. F. (1998). Behavior and interactions of children in cooperative groups in lower and middle elementary grades. Journal of Educational Psychology, 90, 746757.

Gillies, R. M., \& Ashman, A. F. (2000). The effects of cooperative learning on students with learning difficulties in the lower elementary school. Journal of Special Education, 34, 19-27.

Grineski, S. (1993). Achieving instructional goals in physical education: A missing ingredient. Journal of Physical Education, Recreation and Dance, 64, 32-34.

Goudas, M. \& Magotsiou, E. (2009). The Effects of Cooperative Physical Education Program on Student's Social Skill's. Journal of Applied Sport Psychology, 21, 356-364. 
Haring, T.G. (1991). Social Relationships. In L. Meyer, C. A. Peck \& L. Brown. (Eds.), Critical Issues in the lives of people with severe disabilities. (pp. 195-217). Baltimore, MD: Paul H Brookes.

Hymel, S., Vaillancourt, T., Mac Dougall, P., \& Renshaw, P. D. (2002). Acceptance and rejection by the peer group. In Smith, P. \& Hart, C. (Eds.), BlackwellHandbook of Childhood Social Development (pp. 265-284). London: Blackwell Publishers.

Jacques, N., Wilton, K., \& Townsend, M. (1998). Cooperative-learning and social acceptance of children with mild intellectual disabilities. Journal of Intellectual Disabilities Research, 42, 29-36.

Johnson, D.W., \& Johnson, R.T. (1989). Cooperation and competition: Theory in the research. Edina, MN: Interaction Book CO.

Johnson, D. W., \& Johnson, R. T. (2000). The three Cs of reducing prejudice and discrimination. In S. Oskamp (Ed.), Reducing prejudice and discrimination (pp. 239-268). Mahwah, NJ: Lawrence Erlbaum.

Jordan, J. S., \& Turner B. A., (2008). The Feasibility of Single-Item Measures for Organizational Justice Measurement in Physical Education and Exercise Science, 12, 237-257.

Jordan, D., \& Le Metals, J. (1997). Social skilling through cooperative learning. Educational Research, 39, 3-21.

Landers-Potts, M., \& Grant, L. (1997). Competitive climates, athletic skill and children's status in after-shool recreationnal sports programs. Social Psychology of Education, 2, 297-313.

Lloyd, J. W., Crowley, P., Kohler, F. W, \& Strain, P. S. (1988). Redefinig the applied research agenda: Cooperative-learning, prereferral taecher consultation, and peer mediated interventions. Journal of Learning Disabilities, 21, 43-52.

Maassen, G. H., Van der Linden, J. L., Goosens, F. A., \& Bokhorst, J. (2000). A ratings-based appoach to two-dimensional sociometric status determination. In A. H. Cillessen \& W. M. 
Bukowski (Eds.), Recent advances in the measurement of acceptance and rejection in the peer system (pp. 55-73). San Francisco: Jossey-Bass.

Maassen, G. H., \& Verschueren, K. (2005). A two dimensional ratings-based procedure for sociometric status determination as an alternative to the Asher and Dodge System. MerrillPalmer Quaterly, 51, 192-212.

Margolis, H., \& Freund, L. A. (1991). Implementing cooperative learning with mildly handicapped students in regular classrooms. International Journal of Disability, Development and Education, 31, 117-133.

Mascret, N. (2009). Les interactions « joueur-coach » en badminton et leur impact sur les apprentissages en EPS des élèves difficiles [Player-coach interactions in badminton and their impact on the learning of failing students in PE]. eJRIEPS, 16, 55-72.

M.E.N. (2002). Adaptation et intégration scolaires : des ressources au service d'une scolarité réussie pour tous les élèves [Adaptation and integration: ressources for a good scolarity for all students], Paris: Circulaire $\mathrm{n}^{\circ} 111$ du 30 avril 2002.

Newcomb, A. F., Bukowski, W. M., \& Pattee,L. (1993). Children's peer relations: A metaanalytic review of popular, rejected, neglected, controversial, and average sociometric status. Psychological Bulletin. 113, 99-128.

Ochoa, S. H., \& Olivarez, A. (1995). A meta-analysis of peer rating sociometric studies of pupils with learning disabilities. The Journal of Special Education, 29, 1-19.

Oden, S., \& Asher, S. R. (1977). Coaching children in social skills for friendship making. Child Development, 48, 495-506.

Parlebas, P. (1992). Sociométrie, réseaux et communication [Sociometry, networks and communication]. Paris: PUF. 
Pasquier, J. L. (1999). L'intégration des S.E.G.P.A. dans les collèges en 1992 peut-elle nous éclairer au XXI siècle? [Does S.E.G.P.A.s integration light us at the 21th century]. $L a$ Nouvelle Revue de L'A.I.S., 8, 32-37.

Piearcy, M., Wilton, K., \& Townsend, M. (2002). Promoting the social acceptance of young children with moderate-severe intellectual disabilities using cooperative techniques. American Journal of Mental Retardation, 5, 352-360.

Polvi, S., \& Telama, R. (2000). The Use of Cooperative Learning as a Social Enhancer in Physical Education. Scandinavian Journal of Educational Research, 44, 105-115.

Putnam, J. W. (1998). Cooperative learning and strategies for inclusion: celebrating diversity in the classroom. Baltimore: Brookes.

Putnam, J. W., Markovchick, K., Johnson, D. W., \& Johnson, R. T. (1996). Cooperative learning and peer acceptance of students with learning disabilities. The Journal of Social Psychology, $136,741-752$.

Putnam, J. W., Rynders, J. E., Johnson, R. T., \& Johnson, D. W. (1989). Collaborative skill for promoting interactions between mentally handicapped and non handicapped children. Exceptional Children, 55, 550-557.

Sabornie, E., Evans, E., \& Cullinan, C. (2006). Comparing Characteristics of High-Incidence Disability Groups. Remedial and Special Education, , 27, 95-104.

Shessel, H. B., \& Reiff, S. (1999). Experiences of adults with learning disabilities: Positive and negative impacts and outcomes. Learning Disability Quarterly, 22, 305-316.

Slavin, R. E. (1996). Research on cooperative learning and achievement: What we know, what we need to know. Contemporary Educational Psychology, 21, 43-69.

Weiss, M. R., \& Duncan, S. C. (1992). The relationship between physical competence and peer acceptance in the context of children's sports participation. Journal of Sport \& Exercise Psychology, 88, 102-120. 
Weiss, M. R., \& Stuntz, C. P. (2004). A little friendy competition: Peer relationships and psychosocial development in youth sport and physical activity contexts. In M. R. Weiss (Ed.), Developmental sport and exercise psychology: A lifespan perspective (pp. 165-196). Morgantown, WW: Fitness Information Technology. 